\title{
Macro Nutrient Status and Mapping in Santpur Micro-Watershed of Bidar District, Karnataka, India
}

\author{
S. Rashmi ${ }^{*}$, M. Shivanna ${ }^{1}$, Ashok S. Alur ${ }^{1}$, S. Anil Kumar ${ }^{2}$, \\ B.N. Dhananjayya ${ }^{3}$ and Praveen B. Naikodi ${ }^{4}$
}

${ }^{1}$ Department of Soil Science and Agricultural Chemistry, College of Horticulture Bengaluru, University of Horticultural Sciences, Bagalkot-587104, Karnataka, India

${ }^{2}$ Department of Soil Science and Agricultural Chemistry, RHREC Bengaluru, India

${ }^{3}$ Department of Soil Science and Agricultural Chemistry, College of Horticulture Kolar, India

${ }^{4}$ Department of Soil Science and Agricultural Chemistry, College of Horticulture Bidar, India

*Corresponding author

\section{A B S T R A C T}

\section{Keywords}

Geographic Information

System (GIS), soil, nutrients

Article Info

Accepted:

22 January 2019

Available Online:

10 February 2019
A survey study was carried out to evaluate the fertility status of selected Santpur microwatershed soils of Bidar district, in North Eastern Transitional Zone of Karnataka. Two hundred seventeen surface soil samples were collected grid wise by using satellite and cadastral maps of study area were analysed for their fertility status and mapped by geographic information system (GIS) technique. The study revealed that soils of Santpur micro-watershed were slightly acidic to strongly alkaline in soil reaction, non-saline and low to medium status in organic carbon content. Available nitrogen and potassium were low to high and available phosphorus was low to medium in study area.

\section{Introduction}

Soil is the basic requirement of life on earth. Soil nutrients play a vital role in crop production. Intensively cultivated soils are being depleted with available nutrients especially micronutrients. The nutrients exported out of the farm in crop produces must be necessarily replenished to sustain soil fertility and therefore the production system for which balanced fertilizer application is the prerequisite and there is growing need for site specific balanced fertilizer recommendations according to the crop type, yield level and soil conditions. Therefore, assessment of nutrient constraints of soils that are being intensively cultivated with high yielding crops needs to be carried out.

Soil testing is usually followed by collecting composite soil samples in the fields without geographic reference. The results of such soil testing are not useful for site specific recommendations and subsequent monitoring (Pujari et al., 2016). Soil available nutrients constraints of an area using Global Positioning 
System (GPS) will help in formulating site specific balanced fertilizer recommendation and to understand the status of soil fertility spatially and temporally.

Soil test summaries and soil fertility maps are of vital necessity as reference materials for scientific management of soil. This information will also help to adopt effective strategy on fertilizer use and cropping pattern. In the recent past, the concept of watershed based holistic development has emerged as one of the potential holistic approaches in rainfed areas, leading to higher productivity and sustainability in agriculture. Hence, assessing the fertility status and nutrient mapping of soils are needed to identify the extent of soils deficient in nutrients area for site specific recommendations. Nutritional deficiencies are also leading to increased incidences of many chronic diseases related to heart, diabetes, osteoporosis etc., in many developing nations. The information regarding the status of nutrients and nutrient mapping of soils is needed to implement the concept of watershed approach successfully. Hence, the proposed study is planned with the objective of identifying soil fertility constraints.

\section{Materials and Methods}

The selected Santpur micro-watershed of Bidar district, in North Eastern Transitional Zone of Karnataka is located at $18^{\circ} 08^{\prime} 36.85^{\prime}$, to $18^{\circ} 11^{\prime} 19.82^{\prime}$ ' $\mathrm{N}$ latitudes and $77^{\circ} 25^{\prime} 37.37^{\prime}$ ', to $77^{\circ} 27^{\prime} 01.06^{\prime}$ 'E (Fig. 1) with an average elevation of $608 \mathrm{~m}$ above mean sea level (MSL). The area receives a mean annual rainfall of $897.10 \mathrm{~mm}$ with mean maximum and minimum temperature of $33.68^{\circ} \mathrm{C}$ and $21.05{ }^{\circ} \mathrm{C}$ respectively. Soils are clay in texture and black in colour.

Extensive traverse of the micro-watershed was carried out as the first step to identify field boundaries and to study external land features.
Using base maps, satellite imagery and toposheets, physiographic delineations were marked in the study area. Traversing was done to confirm the delineations and main physiographic units of the study area were identified. Survey numbers given in the cadastral map were identified in the field. A total of 217 surface samples were collected grid wise $(200 \mathrm{~m})$ according to survey numbers for laboratory analysis. Exact geographical locations of surface soil samples were recorded using a GPS device (82 no.). Soil samples were first air-dried in shade, then powdered and sieved through $2 \mathrm{~mm}$ sieve then stored in clean polyethylene bags. Processed soil samples were analyzed in the laboratory for various physico-chemical parameters $(\mathrm{pH}$ and EC), organic carbon and available major $\left(\mathrm{N}, \mathrm{P}_{2} \mathrm{O}_{5}, \mathrm{~K}_{2} \mathrm{O}\right.$ ) (Table 1).

\section{Soil fertility maps}

Soil fertility maps showing plot wise status of available major nutrients were prepared in GIS environment to know the fertility status of the soils of study area. GIS processing involved geo-referencing of various thematic maps and vectorisation of the features using Arc GIS software. Simultaneously the attribute coding and the description for all feature classes were organized in master database tables. The topography was created and the master database was linked to respective themes. All the features were referenced with the standard codes. The soil, land use and watershed themes were built as polygon features, whereas streams and roads were built as line features. The water resources include line features as well as point features and these were included as shape files.

\section{Results and Discussion}

The data pertaining to the fertility status of Santpur micro-watershed are presented in Table 2 and Figure 2 through 7. 
pH

The $\mathrm{pH}$ of surface soil samples ranged from $6.18-8.62$ with an average value of 7.64 and standard deviation of 0.56 . Soil samples at higher elevation had lower $\mathrm{pH}$ compared to those at valley in the micro-watershed. It is estimated that, 0.32 per cent (Fig. 2) of the total area was slightly acidic, 30.59 per cent was neutral, 27.34 per cent was slightly alkaline, 32.96 per cent was moderately alkaline and remaining only 2.52 per cent was strongly alkaline in reaction (7.6:8.9). The soils studied are under arid to semi-arid region and hence not subjected to leaching losses of cations. Similar values were reported by Ashok (1996) in black soils of the GLBC area. The higher $\mathrm{pH}$ of black soils could be attributed to the accumulation of bases. The results are in agreement with those reported for black soils by Ravikumar et al., (2007) and Manojkumar (2011).

\section{Electrical conductivity (EC)}

The EC values of the Santpur micro-watershed area studied were in normal range (0.07- 0.55

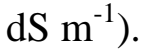

Relatively higher values were observed in the study area in the undulating plains and alluvial plains as salts are expected to be higher in the lower elements of the landscape (Fig. 3). Dasog and Hadimani (1980) reported EC ranging from $0.39-0.53 \mathrm{dS} \mathrm{m}^{-1}$ at surface in GLBC soils.

\section{Organic carbon}

The organic carbon content of the soil was in the range of 0.09 to 0.94 per cent at the surface (Fig. 4). Low organic carbon in the soil might be due to low input of FYM and crop residues as well as their rapid rate of decomposition under high temperature.

Fig.1 Location map of Santpur micro-watershed

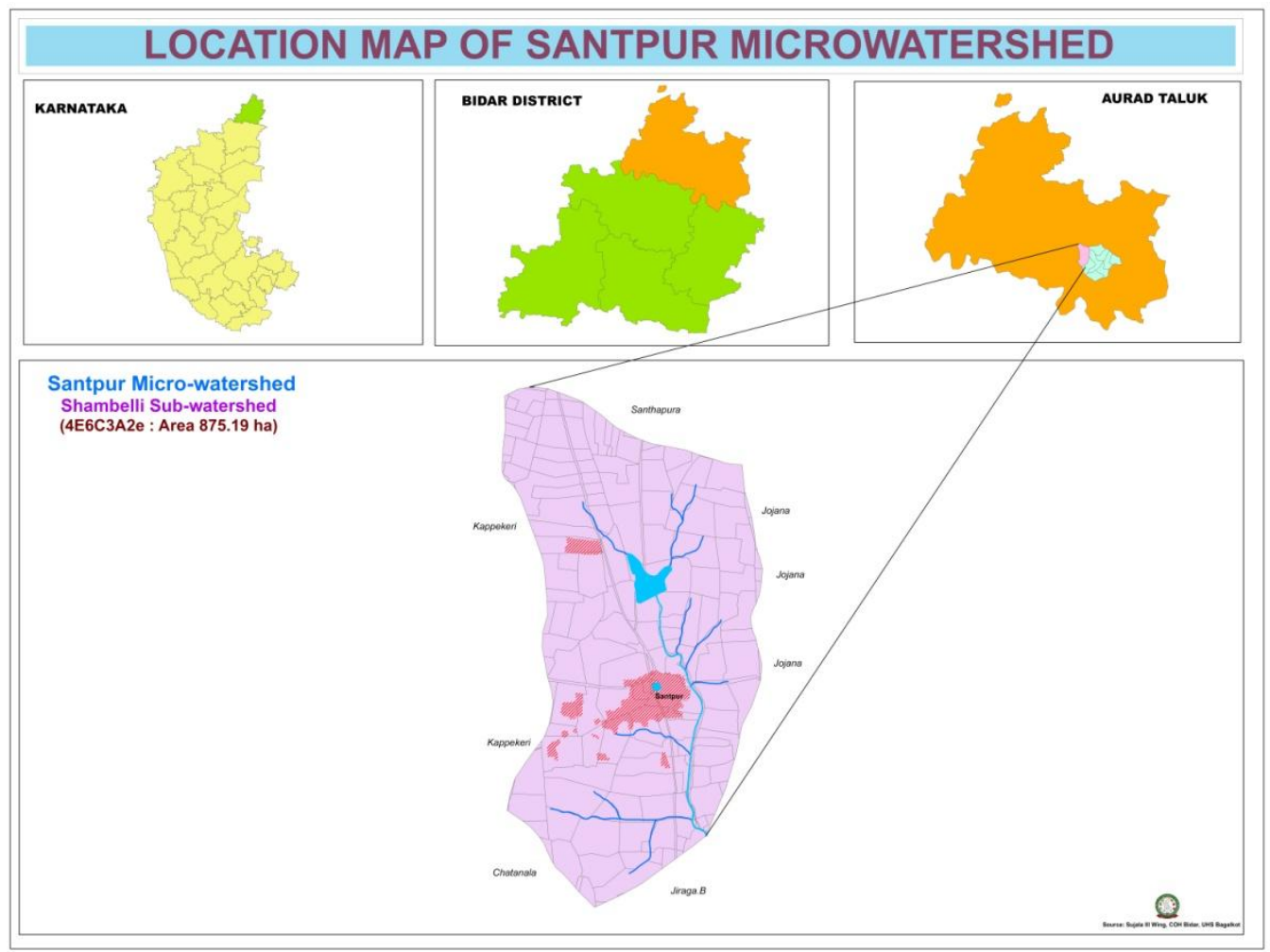


Fig.2 Soil reaction status in surface soils of Santpur micro-watershed

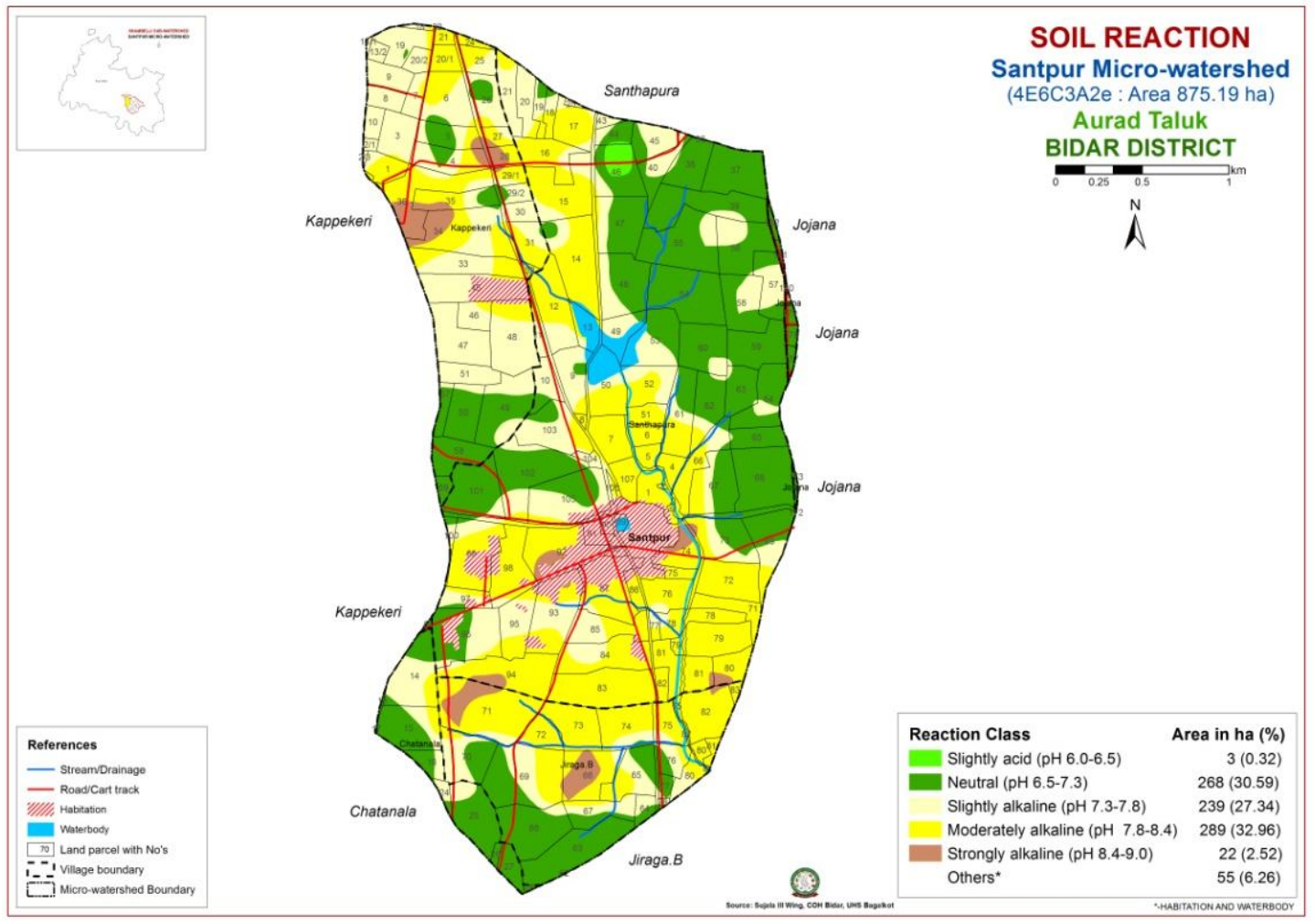

Fig.3 Salinity status in surface soils of Santpur micro-watershed

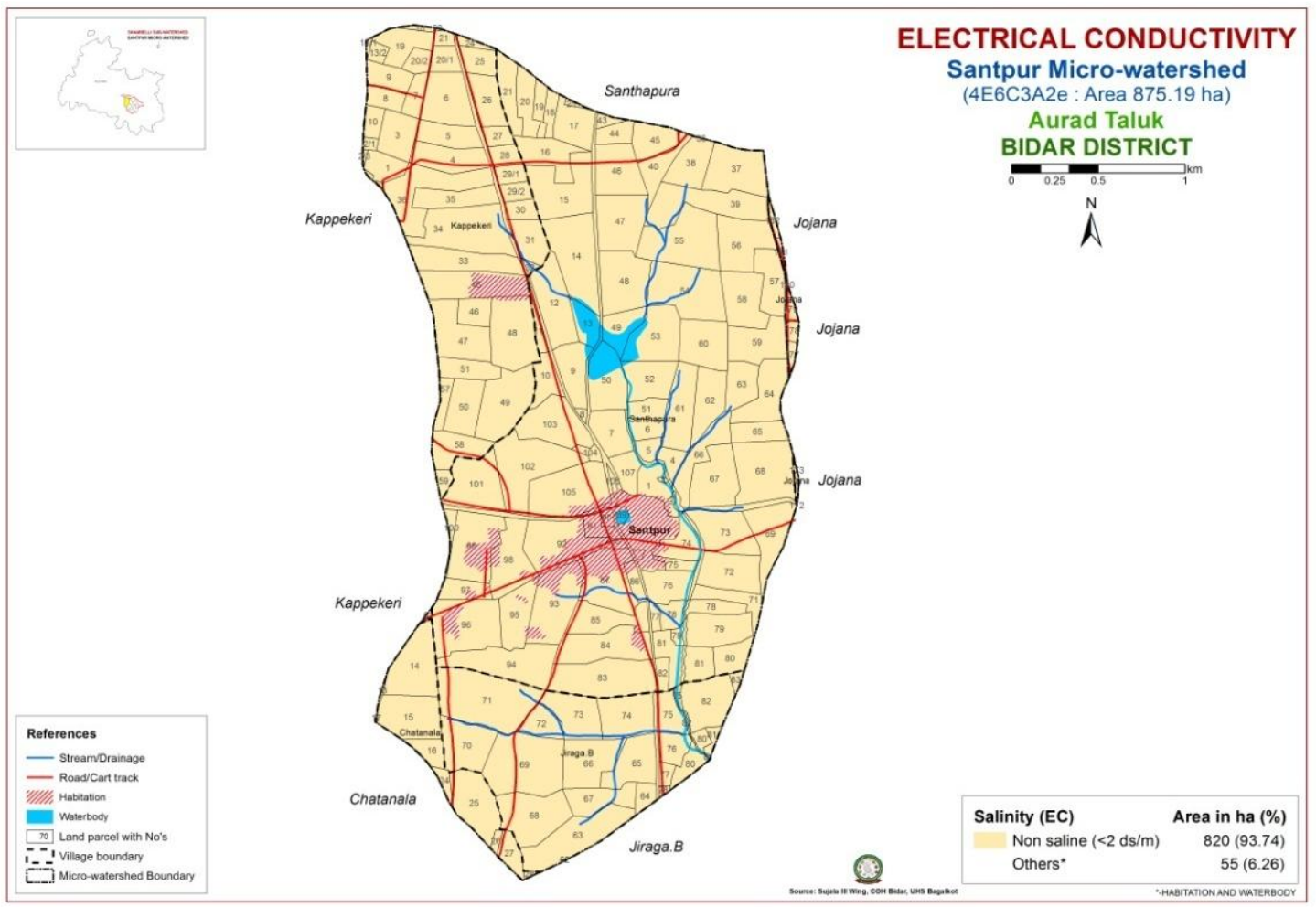


Fig.4 Organic carbon status in surface soils of Santpur micro-watershed

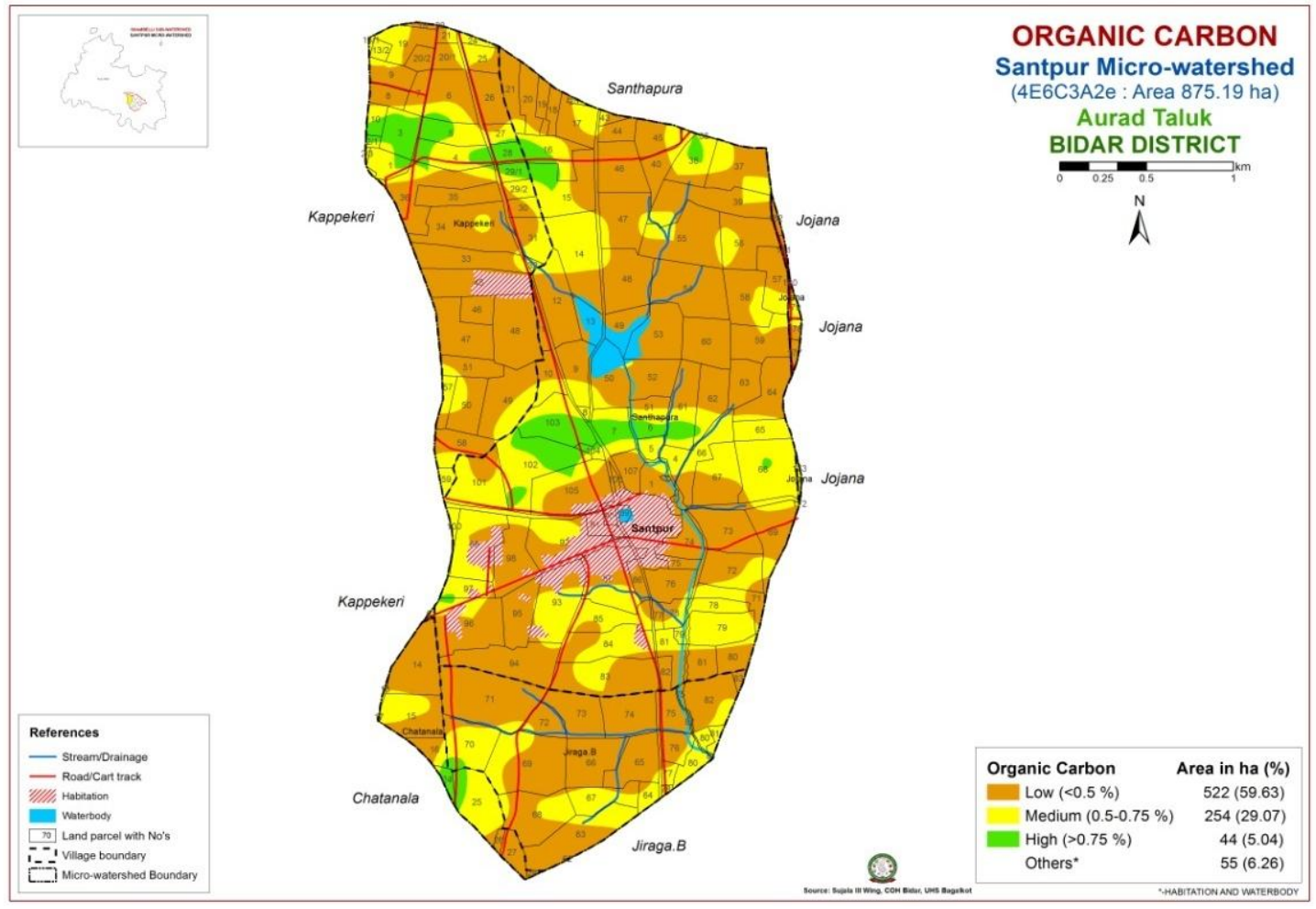

Fig.5 Available nitrogen status in surface soils of Santpur micro-watershed

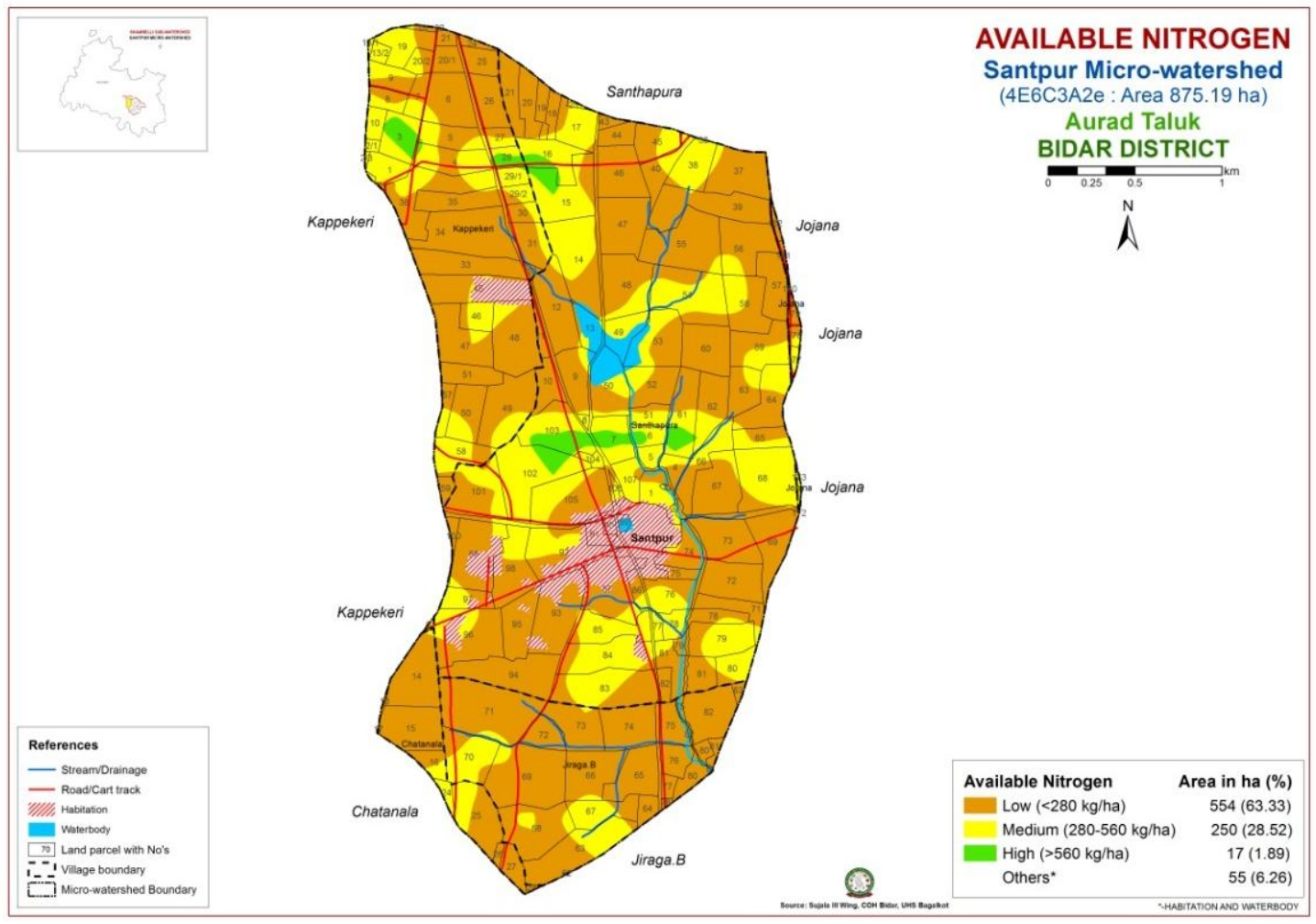


Fig.6 Available phosphorus status in surface soils of Santpur micro-watershed

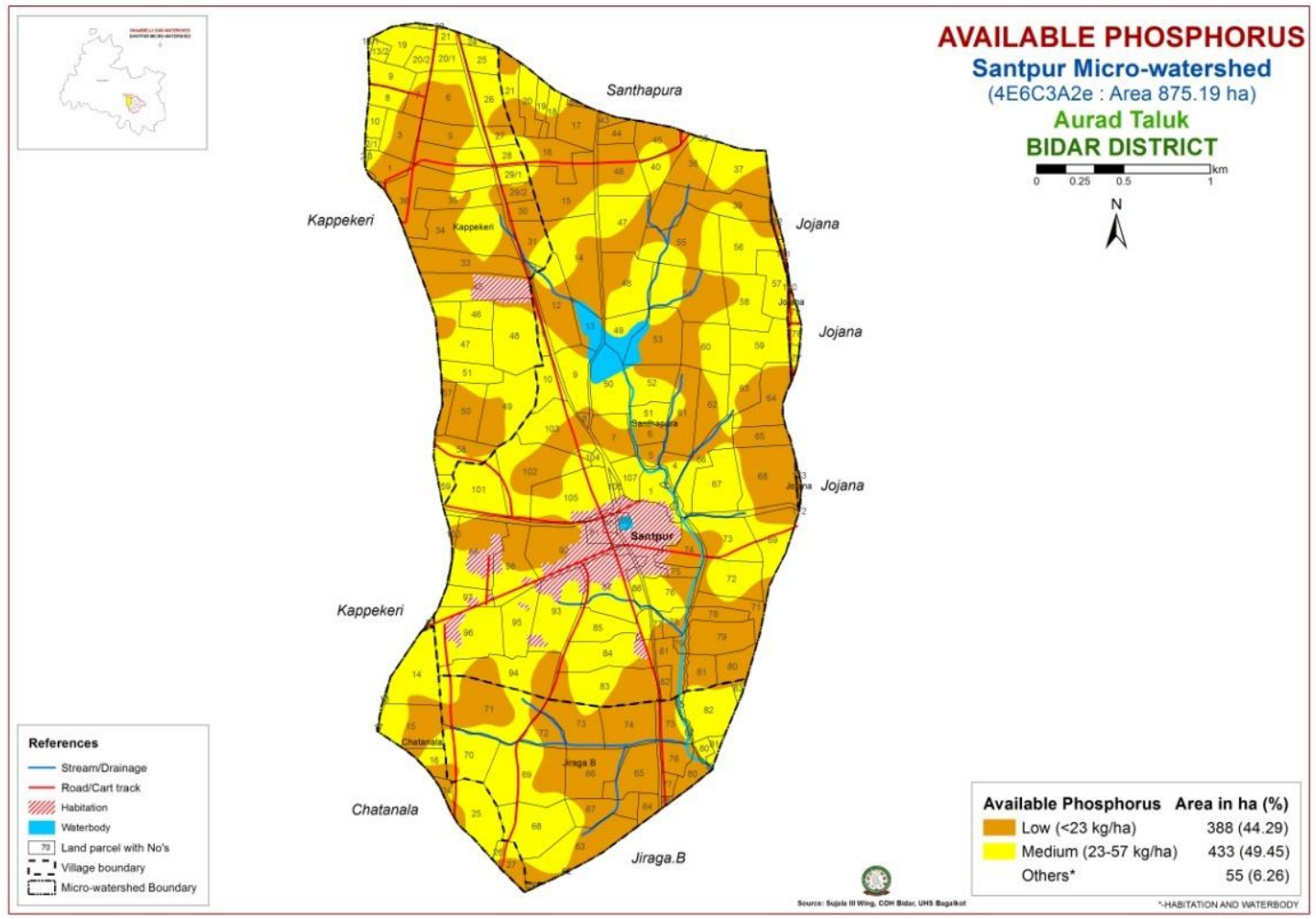

Fig.7 Available potassium status in surface soils of Santpur micro-watershed

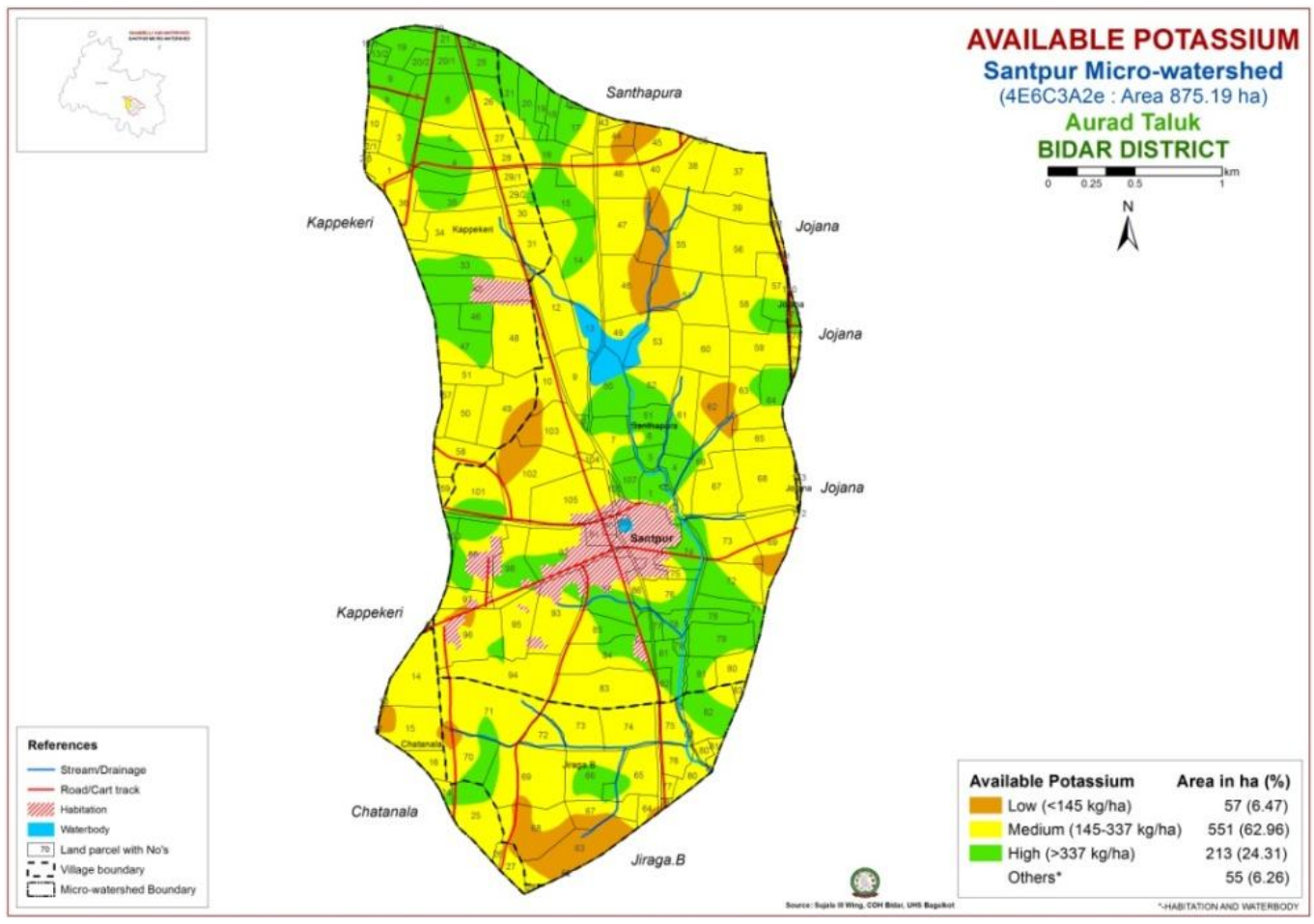


Table.1 Methods adopted for estimation of properties

\begin{tabular}{|c|l|l|}
\hline SI. No & \multicolumn{1}{|c|}{ Soil parameters } & \multicolumn{1}{|c|}{ Methods adopted } \\
\hline 1 & Soil reaction & Jackson,1973 \\
\hline 2 & Electrical conductivity & Jackson,1973 \\
\hline 3 & Organic carbon & Jackson,1973 \\
\hline 4 & Available nitrogen & Subbaiah and Asija,1956 \\
\hline 5 & Available phosphorus & Jackson,1973 \\
\hline 6 & Available potassium & Jackson,1973 \\
\hline
\end{tabular}

Table.2 Fertility status of surface soil at Santpur micro-watershed $(N=217)$

\begin{tabular}{|c|l|c|c|c|}
\hline Sl. No & \multicolumn{1}{|c|}{ Parameters } & Range & Average & SD \\
\hline 1 & $\mathrm{pH}(1: 2.5)$ soil : water ratio & $6.18-8.62$ & 7.64 & 0.56 \\
\hline 2 & $\mathrm{EC}\left(\mathrm{dSm}^{-1}\right)$ & $0.07-0.55$ & 0.16 & 0.07 \\
\hline 3 & $\mathrm{OC}($ per cent $)$ & $0.09-0.94$ & 0.43 & 0.24 \\
\hline 4 & Available $\mathrm{N}\left(\mathrm{kg} \mathrm{ha}^{-1}\right)$ & $112.9-605.38$ & 277.18 & 122.56 \\
\hline 5 & Available $\mathrm{P}_{2} \mathrm{O}_{5}\left(\mathrm{~kg} \mathrm{ha}^{-1}\right)$ & $3.36-53.76$ & 23.83 & 10.86 \\
\hline 6 & Available $\mathrm{K}_{2} \mathrm{O}\left(\mathrm{kg} \mathrm{ha}^{-1}\right)$ & $93.53-418.01$ & 274.80 & 107.53 \\
\hline
\end{tabular}

The organic matter degradation and removal takes place at faster rate particularly under low vegetation cover resulting in less accumulation of organic matter in the soil. Similar observations were also made by Nayak et al., (2002) in loamy sand soils of Central Research Station, Bhubaneswar.

\section{Available nitrogen}

Major area of Santpur micro-watershed was found low in available nitrogen. The soil nitrogen ranged from 112.90 to $605.38 \mathrm{~kg} \mathrm{ha}^{-1}$ with mean of $277.18 \mathrm{~kg} \mathrm{ha}^{-1}$ (Fig. 5). The variation in $\mathrm{N}$ content may be related to soil management, application of FYM and fertilizer to previous crop.

The low available nitrogen content in the area could be attributed to low OC status of soil coupled with low nitrogen fertilization leading to nitrogen deficiency. The results obtained in the present study are in agreement with the findings of Mathews et al., (2009) and Ravikumar et al., (2007a).

\section{Available phosphorus}

The available phosphorus content was medium in major parts of the watershed (433 ha), but it was low in 388 ha (Fig. 6). The low values are due to low CEC, clay content and soil reaction. The present findings are in line with those of Bopathi and Sharma (2006) and Shiva Prasad et al., (1998) who reported that majority of the soils in Karnataka were medium in phosphorus content.

\section{Available potassium}

The soils of the study area were found to be low to high in available potassium with range of 93.53 to $418.01 \mathrm{~kg} \mathrm{ha}^{-1}$ (Fig. 7). Around 24.31 per cent (213 ha) of the Santpur microwatershed area recorded high $\mathrm{K}$ values, while 62.96 per cent of the area (551 ha) had medium and only 6.47 per cent of the area (57 ha) had medium available potassium content. Parashivamurthy (1988) and Shivaprasad et al., (1988) also reported medium to high K status in black soils of Karnataka. It is observed that many vertisols are able to maintain a sufficient 
or even high level of exchangeable $\mathrm{K}$ and can provide a good supply of $\mathrm{K}$ to plants for many years (Finck and Venkateswarlu, 1982).

From the study, it can be concluded that, soils of Santpur micro-watershed of Bidar district, in North Eastern Transitional Zone of Karnataka are low in soil organic carbon content. Available nitrogen and potassium were low to high and available phosphorus was low to medium in entire study area. Mapping of nutrients by GIS techniques revealed that major portion of the study area was deficient in available $\mathrm{N}$ and $\mathrm{P}$ are important soil fertility constraints indicating their immediate attention for sustained crop production. The deficient nutrient may be replenished to avoid the crops suffering from their deficiency and for optimum utilization of other nutrients.

\section{References}

Ashok, L. B., 1996. Micronutrient fertility map of Ghataprabha command area of Belgaum district. M. Sc. (Agri.) Thesis, Univ. Agric. Sci., Dharwad (India).

Bopathi, H. K. and Sharma, K. N., 2006. Phosphorus adsorption and desorption characteristics of some soils as affected by clay and available phosphorus content. J. Indian Soc. Soil Sci., 54(1): 111-114.

Dasog, G. S. and Hadimani, A. S., 1980. Genesis and chemical properties of some Vertisols. J. Indian Soc. Soil Sci., 28: 4956.

Finck, A. and Venkateswarlu, J., 1982. Vertisols and rice soils of the tropics. Paper presented Symposia Papers II 12th Int. Cong. Soil Sci., New Delhi, pp-45-48.
Jackson, M. L., 1973. Soil Chemical Analysis. Prentice Hall of India, Pvt. Ltd., New Delhi.

Manojkumar, D., 2011. Characterization and classification of soils of a microwatershed on basalt parent rock in northern transition zone of Karnataka. M. Sc (Agri) Thesis, Univ. Agric. Sci., Dharwad (India).

Mathews, D., Patil, P. L. and Dasog, G. S., 2009. Identification of soil fertility constraints of a pilot site in coastal agro ecosystem of Karnataka by geographic information system technique. Karnataka J. Agric. Sci., 22(1): 77-80.

Nayak, R. K., Sahu, G. C. and Nanda, S. S. K., 2002. Characterization and classification of the soils of Central Research Station, Bhubaneswar. Agropedology, 12: 1-8.

Parashivamurthy, A. S., 1988. Distribution, proportion and management of vertisols of India. Adv. Soil Sci., 8: 151-200.

Pujari, K. L., Patil, P. L., Dasog, G. S., Hebsur, N. S., Manjunath, M. V. and Alagundagi, S. C., 2016. Identification of soil fertility constraints by geographic information system technique in Kotur microwatershed. J. Farm Sci., 29(1): 32-36.

Ravikumar, M. A., Patil, P. L. and Dasog, G. S., 2007. Mapping of Nutrients Status of 48A Distributary of Malaprabha Right Bank Command of Karnataka by GIS Technique. I-Major Nutrients". Karnataka J. Agric. Sci., 20(4): 735-737

Shiva Prasad, C.R., Reddy, R.S., Sehgal, J. and Velayutham, M., 1998. Soils of Karnataka for optimizing land use. NBSS Publications 47, p. 15.

Subbiah, B. V. and C. L. Asija, 1956. A rapid procedure for estimation of available nitrogen in soils. Curr. Sci., 25: 259-260.

\section{How to cite this article:}

Rashmi, S., M. Shivanna, Ashok S. Alur, S. Anil Kumar, B.N. Dhananjayya and Praveen B. Naikodi. 2019. Macro Nutrient Status and Mapping in Santpur Micro-Watershed of Bidar District, Karnataka, India. Int.J.Curr.Microbiol.App.Sci. 8(02): 3274-3281. doi: https://doi.org/10.20546/ijcmas.2019.802.382 